\title{
Three-Year Longitudinal Survey of Changes in Consciousness about Mathematics in Junior High School Students and Its Relationship with Academic Achievement
}

\author{
Kohei Okado$^{1}$, Noriyuki Kida², Takeshi Sakai ${ }^{3}$ \\ ${ }^{1}$ Vories Gakuen Omi Brotherhood Junior High School, Shiga, Japan \\ ${ }^{2}$ Kyoto Institute of Technology, Kyoto, Japan \\ ${ }^{3}$ Kyoto Women's University, Kyoto, Japan \\ Email: cowhey@gmail.com
}

How to cite this paper: Okado, K., Kida, N., \& Sakai, T. (2019). Three-Year Longitudinal Survey of Changes in Consciousness about Mathematics in Junior High School Students and Its Relationship with Academic Achievement. Psychology, 10, 46-61.

https://doi.org/10.4236/psych.2019.101004

Received: December 1, 2018

Accepted: January 11, 2019

Published: January 14, 2019

Copyright $\odot 2019$ by author(s) and Scientific Research Publishing Inc.

This work is licensed under the Creative Commons Attribution International License (CC BY 4.0).

http://creativecommons.org/licenses/by/4.0/

\begin{abstract}
This study explored correlation between changes of consciousness and academic achievement about mathematics across the 3 years on junior high school in Japan. The purpose of this study was to develop and assess the item of consciousness about mathematics in junior high school. For that reason a 3-year longitudinal survey was conducted in a private junior high school for three generations. First, an exploratory factor analysis was conducted, which extracted two factors: "Interest score" and "Quantitative learning score". Then, correlations between the two factors and academic achievement were investigated. Results indicated that Interest score had a strong correlation with academic achievement for mathematics and the Quantitative learning score had a weak correlation with academic achievement. These results suggest that educational activities focusing on the consciousness about mathematics are useful for improving mathematical education of junior high school students.
\end{abstract}

\section{Keywords}

Junior High School, Mathematics Education, Interest, Quantitative Learning

\section{Introduction}

Early adolescence (12 - 15 years of age) is a period of many changes. One of these changes is the transition from elementary school to junior high school. The Carnegie Council on Adolescent Development (1995) suggests the importance of 
focusing on changes occurring during the transition from elementary school to junior high school. Many young people experience a decline in academic achievement and motivation during this period (Eccles and Midgley, 1989; Eccles et al., 1993). Simmons and Blyth (1987) reported that changes during this period sometimes lead not only to a decline in academic achievement but also to failure and withdrawal from school. It has been reported that Junior high school students in Japan also experience a decline in motivation to study during this time. According to the "Survey on National Academic Ability and Learning Situation" in Japan, the study motivation of junior high school students in grade three is much lower than sixth graders in elementary school (MEXT, 2017). In addition, studies of private junior high schools in Japan show that learning habits decline dramatically in the first year after the transition from elementary to junior high school (Okado et al., 2017).

Anderman and Midgley (1997) analyzed differences in learning between elementary school and junior high school students and reported that elementary school students try to improve their abilities and seek better task performance. On the other hand, junior high school students tend to seek relative evaluations, where they are content with their score in reference to the average only and merely try to obtain results, such as finding the correct answer. This could be an indication of junior high school students' declining interest in learning, which is known to have a significant influence on academic achievement. The above findings are related to the learning of junior high school students in general and do not include specialized subjects.

\subsection{Studies on Mathematics Education}

Studies on mathematics education in Japan have also reported that junior high school students have a significantly reduced interest in mathematics compared to elementary school students. The "Survey on National Academic Ability and Learning Situation" conducted by the Ministry of Education, Culture, Sports, Science and Technology (2017) reported that all the questions regarding mathematical consciousness in the survey indicated that $3^{\text {rd }}$-grade junior high school students have less interest than $6^{\text {th }}$-grade elementary school students. Moreover, the results of the "International Mathematics and Science Education Trend Survey" conducted by the International Education Achievement Assessment Association (IEA) indicated that junior high school students compared to elementary school students responded with lower values to the questions "mathematics is fun", and "mathematics is good" (MEXT, 2015), which is indicative of a declining interest in mathematics. This suggests that the declining interest in mathematics occurs in the three years after the transition from elementary to junior high school. Therefore, it is necessary to understand students' consciousness during the junior high school period and clarify the relationship between consciousness and academic achievement.

Uchida and Mori (2012) pointed out "Little is known about why Japanese 
children dislike mathematics and science. Moreover, it is problematic that there are only a few studies on junior high school students, who seem to be particularly important". A longitudinal survey on changes in the consciousness about mathematics during the junior high school period is explicitly needed to clarify the tendency and factors related to the decline in consciousness about mathematics and develop interventions designed to improve the consciousness about mathematics. Such a study is considered to be essential for improving mathematics education in Japan.

\subsection{Literature Reviews}

Recent studies have focused on high school students, even though mathematical and scientific interests in junior high school students are known to be correlated with future careers in these subjects (Reynolds, 1991).

In Japan, only a few studies have been conducted on the motivation for mathematical education and its relationship to academic achievement (Uchida \& Mori, 2012). Kawachi, Chuman, Iwata (2000) investigated about cause of declining the mathematics motivation. Oie, and Fujie (2007) found that the cause of declining the mathematics motivation is occurred during elementary school. They suggest that it is important to improving mathematical education at the transition from elementary school to junior high school.

Moreover previous research suggested that the factors as motivation, interest, attitude, and academic engagement were strong correlation with academic achievement. So these factors could predict mathematics achievement and avoidance on the part of students (Eccles \& Jacobs, 1986; Reynolds \& Walberg, 1992).

Skaalvik and Rankin (1995) found that motivation of mathematics is correlated with academic achievement. However, knowledge of junior high school students' motivation for mathematics education is insufficient, and the correlation between the consciousness and academic achievement of junior high school students is unclear.

\subsection{Research Purpose}

This study explored correlation between changes of consciousness and academic achievement about mathematics across the 3 years on junior high school in Japan. The purpose of this study was to develop and assess the item of consciousness about mathematics in junior high school. It is necessary to develop a scale for assessing changes in junior high school students' consciousness about mathematics and clarify correlations between academic achievement and consciousness about mathematics, to understand this relationship better. This study was designed to clarify correlations between the transformation of consciousness on mathematics that occur during junior high school and changes in motivations and academic achievement by conducting a longitudinal investigation. The study was designed to sample three generations of junior high school students during three years. It is expected that the results would help develop useful methods of supporting the mathematics education of individual junior high school students. 


\section{Method}

\subsection{Participants}

Participants were three generations of students that were enrolled in a private junior high school. A longitudinal survey was conducted in 5 waves (the fall of $1^{\text {st }}, 2^{\text {nd }}$, and $3^{\text {rd }}$ year, and the spring of $2^{\text {nd }}$ and $3^{\text {rd }}$ year). Each generation participated for 5 waves, from fall of their $1^{\text {st }}$-year to fall of their $3^{\text {rd }}$-year. Each wave represents a semester of school. Participants included $1^{\text {st }}$ generation $(\mathrm{N}=142)$, $2^{\text {nd }}$ generation $(\mathrm{N}=151)$, and $3^{\text {rd }}$ generations $(\mathrm{N}=163)$ students.

\subsection{Survey Contents and Survey Period}

The participants responded to nine questions that assessed their consciousness about mathematics. The company of Benesse Corporation conducted the questionnaire and the results were quantified and provided to our school.

The questions are "Tell me the learning time to study mathematics on weekdays?" "Tell me learning time of mathematics on holiday?" "How do you prepare for regular examination of mathematics?" "Do you like studying mathematics?" "What kind of impression do you have about mathematics learning until now?" "Tell me your approach about mathematics lesson?" "How long do you prepare for regular examination of mathematics?" "Do you review the results of mathematics examination?" "How do you approach to mathematical applied problems and unsolvable problems?".

Answers to the question items were evaluated with a five-point scare, a six-point scale, and a eight-point scale and the answers were normalized to 100 points and used for analysis. This longitudinal investigation that continued for over three years was conducted in two waves during each year in the spring and the fall.

The comprehensive academic achievement of mathematics was assessed during the spring and the fall terms. The achievement in the $3^{\text {rd }}$ year was predicted from the comprehensive academic achievement in the mathematics test that was held in the spring term of the first-year. The residual between predicted achievement in the fall of the $3^{\text {rd }}$ year and the actual score was calculated. These residuals were considered as the increase in achievement.

\subsection{Data Analysis}

The structures of the consciousness concerning mathematics were analyzed using factor analysis. Then, an analysis of variance (ANOVA), multiple comparisons, correlation analysis, and multiple regression analysis was conducted. SPSS 23.0 was used for data analysis.

\section{Results}

\subsection{Factor Analysis}

First, average values and standard deviations for the nine items of the con- 
sciousness about mathematics were determined. In order to identify the ceiling and floor effects for each item, the average value \pm standard deviation of the range from the minimum to the maximum value was determined. The average value and standard deviation of each item are shown in Table 1.

As can be seen from Table 1, all items excluding items 3 and 7 satisfied the criterion minimum value $\leq$ the average rating value \pm standard deviation $\leq$ the maximum value. A ceiling effect was observed in items 3 and item 7 , and they were excluded from the analysis. An analysis using the re-likelihood method with Promax rotation was performed on the 7 remaining items, and those items with an insufficient factor-loading (0.40) were excluded from the analysis.

The final factor patterns and factor correlations are displayed in Table 2.

Two factors were extracted as a result of the factor analysis. The first factor was named the "Interest score" because it consisted of items showing an interest in mathematics and items expressing liking or disliking mathematics had a high loading on this factor. The second factor was named the "Quantitative learning score" because items indicating mathematics learning time had a high loading on this factor. In addition, the $\alpha$ coefficients of items constituting each factor were calculated to examine the internal consistency of the factors, which indicated

Table 1. The average value and standard deviation of each item.

\begin{tabular}{lrrrr}
\hline & items of questionnaire & AV \pm SD & Min & Max \\
\hline 1 & Learning time after mathematics class & $28.87 \pm 14.2$ & 12.5 & 100 \\
2 & Holidays learning time (mathematics) & $31.88 \pm 17.8$ & 12.5 & 100 \\
3 & Learning for regular examination of mathematics & $91.61 \pm 13.8$ & 20.0 & 100 \\
4 & About learning mathematics (likes and dislikes) & $57.53 \pm 26.5$ & 20.0 & 100 \\
5 & Impression of mathematics & $72.41 \pm 21.5$ & 16.7 & 100 \\
6 & Approach to mathematics class & $57.52 \pm 22.6$ & 16.7 & 100 \\
7 & Learning before regular examination of mathematics & $76.72 \pm 26.1$ & 16.7 & 100 \\
8 & Review after regular examination of mathematics & $63.07 \pm 17.7$ & 20.0 & 100 \\
9 & Approaches to mathematical applied problems and & $67.71 \pm 19.7$ & 20.0 & 100 \\
\hline
\end{tabular}

Table 2. The final factor patterns and factor correlations.

\begin{tabular}{ccc}
\hline \multicolumn{1}{c}{ F1 } & F1 & F2 \\
\hline Impression of mathematics & & \\
\cline { 2 - 2 } F2 & 0.809 & 0.135 \\
About learning mathematics (likes and dislike) & 0.736 & 0.151 \\
Approach to mathematics class & 0.588 & 0.262 \\
Learning time after mathematics class & & \\
Holidays learnig time (mathematics) & 0.141 & 0.762 \\
Factor correlation & 0.191 & 0.519 \\
\hline
\end{tabular}


the following coefficients: Interesting score factor $(\alpha=0.75)$ and the Quantitative learning score factor $(\alpha=0.56)$. Moreover, a correlation analysis between the factor scores indicated a significant correlation between the two factor scores $(\mathrm{r}=0.29, p<0.01)$.

\subsection{Differences Based on Timing}

The average value and the standard deviation at each time point in the Interest score and the Quantitative learning score are shown in Table 3.

A one-factor analysis of variance conducted for each score with time as the between factor variable indicated no significant main effect on the Interest score, whereas a significant main effect was observed on the Quantitative learning score. The results of multiple comparisons indicated that the Quantitative learning score was the lowest in the fall of the $2^{\text {nd }}$-year, which was significantly lower than the fall of the $1^{\text {st }}$-year, the spring of the $2^{\text {nd }}$-year, the spring of $3^{\text {rd }}$-year, and the fall of the $3^{\text {rd }}$-year.

\subsection{Relationships between the Interest Score, the Quantitative Learning Score, and Academic Achievement}

Table 4 shows the correlation coefficients between the Interest score in each period with comprehensive academic achievement in mathematics at each time point, for each problem group.

It can be seen from Table 4 that there is a significant positive correlation between all comprehensive academic achievement scores and the Interest score. A significant positive correlation was also observed between the Interest score from the fall of the $1^{\text {st }}$-year and the fall of the $2^{\text {nd }}$-year as well as improvement in academic achievement. Moreover, the scores for each problem group indicated a significant correlation between the Interest score at all periods and calculation problem score, as well as the basic problem.

Table 5 shows the correlation coefficients between the Quantitative learning score in each period with the comprehensive academic achievement in mathematics at each time point, for each problem group.

It can be seen from Table 5 that there is a significant positive correlation between the Quantitative learning scores in the spring of the $2^{\text {nd }}$-year and academic achievement in the fall of the $1^{\text {st }}$-year, the spring and the fall of the $2^{\text {nd }}$-year, and the spring and the fall of the $3^{\text {rd }}$-year. In addition, there was a significant positive

Table 3. The average value and the standard diviation at each time point in the Interest scores and Quantitative learning score.

\begin{tabular}{|c|c|c|c|c|c|c|}
\hline & $1^{\text {st }}$ year & $2^{\text {nd }}$ year & & $3^{\text {rd }}$ year & & \\
\hline & fall & spring & fall & spring & fall & \\
\hline & $\mathrm{M} \pm \mathrm{SD}$ & $\mathrm{M} \pm \mathrm{SD}$ & $\mathrm{M} \pm \mathrm{SD}$ & $\mathrm{M} \pm \mathrm{SD}$ & $\mathrm{M} \pm \mathrm{SD}$ & \\
\hline interest score & $0.02 \pm 0.86$ & $-0.02 \pm 0.88$ & $-0.02 \pm 0.89$ & $-0.06 \pm 0.89$ & $0.08 \pm 0.91$ & \\
\hline $\begin{array}{l}\text { quantitative learning } \\
\text { score }\end{array}$ & $0.01 \pm 0.74$ & $-0.02 \pm 0.75$ & $-0.21 \pm 0.69$ & $0.12 \pm 0.90$ & $0.10 \pm 0.90$ & $\begin{array}{c}\text { fall of } 2^{\text {nd }}<\text { fall of } 1^{\text {st }} \text { and } 3^{\text {rd }}, \\
\text { spring of } 2^{\text {nd }} \text { and } 3^{\text {rd }}\end{array}$ \\
\hline
\end{tabular}


Table 4. The correlation coefficients between the Interest score in each period with comprehensive academic achievement, for each problem group.

\begin{tabular}{|c|c|c|c|c|c|c|c|}
\hline & \multicolumn{2}{|c|}{$1^{\text {st }}$ year } & \multicolumn{2}{|c|}{$2^{\text {nd }}$ year } & \multicolumn{2}{|c|}{$3^{\text {rd }}$ year } & \multirow{2}{*}{ improvement } \\
\hline & spring & fall & spring & fall & spring & fall & \\
\hline the Interest score & \multicolumn{7}{|c|}{ comprehensive academic achievement } \\
\hline fall of $1^{\text {st }}$ year & $0.461^{* *}$ & $0.529^{* *}$ & $0.515^{* *}$ & $0.513^{* *}$ & $0.518^{* *}$ & $0.476^{* *}$ & $0.182^{* *}$ \\
\hline spring of $2^{\text {nd }}$ year & $0.452^{* *}$ & $0.521^{* *}$ & $0.525^{\star *}$ & $0.526^{* *}$ & $0.554^{\star *}$ & $0.511^{\star *}$ & $0.136^{*}$ \\
\hline fall of $2^{\text {nd }}$ year & $0.461^{* *}$ & $0.493^{* *}$ & $0.529^{* *}$ & $0.577^{\star *}$ & $0.605^{\star *}$ & $0.548^{* *}$ & $0.115^{\star}$ \\
\hline spring of $3^{\text {rd }}$ year & $0.444^{* *}$ & $0.497^{* *}$ & $0.540^{* *}$ & $0.589^{* *}$ & $0.616^{* *}$ & $0.562^{* *}$ & 0.075 \\
\hline fall of $3^{\text {rd }}$ year & $0.499^{* *}$ & $0.544^{* *}$ & $0.558^{* *}$ & $0.600^{* *}$ & $0.655^{\star *}$ & $0.639^{* *}$ & 0.078 \\
\hline the Interest score & \multicolumn{7}{|c|}{ calculation problem } \\
\hline fall of $1^{\text {st }}$ year & $0.335^{\star *}$ & $0.479^{* *}$ & $0.456^{* *}$ & & $0.439^{* *}$ & $0.434^{* *}$ & \\
\hline spring of $2^{\text {nd }}$ year & $0.361^{* *}$ & $0.488^{* *}$ & $0.451^{* *}$ & & $0.455^{* *}$ & $0.471^{* *}$ & \\
\hline fall of $2^{\text {nd }}$ year & $0.343^{* *}$ & $0.452^{* *}$ & $0.450^{\star *}$ & & $0.527^{\star \star}$ & $0.511^{\star *}$ & \\
\hline spring of $3^{\text {rd }}$ year & $0.334^{* *}$ & $0.456^{* *}$ & $0.455^{\star *}$ & & $0.519^{* *}$ & $0.514^{* *}$ & \\
\hline fall of $3^{\text {rd }}$ year & $0.360^{* *}$ & $0.459^{* *}$ & $0.483^{* *}$ & & $0.597^{\star *}$ & $0.568^{* *}$ & \\
\hline the Intrest score & \multicolumn{7}{|l|}{ basic problem } \\
\hline fall of $1^{\text {st }}$ year & $0.363^{* *}$ & $0.388^{* *}$ & $0.381^{* *}$ & $0.452^{* *}$ & $0.399^{* *}$ & $0.417^{\star *}$ & \\
\hline spring of $2^{\text {nd }}$ year & $0.390^{* *}$ & $0.446^{* *}$ & $0.435^{\star *}$ & $0.456^{* *}$ & $0.423^{* *}$ & $0.429^{* *}$ & \\
\hline fall of $2^{\text {nd }}$ year & $0.406^{* *}$ & $0.369^{* *}$ & $0.393^{* *}$ & $0.548^{* *}$ & $0.448^{\star *}$ & $0.481^{* *}$ & \\
\hline spring of $3^{\text {rd }}$ year & $0.397^{* *}$ & $0.411^{* *}$ & $0.446^{\star *}$ & $0.549^{* *}$ & $0.482^{* *}$ & $0.499^{* *}$ & \\
\hline fall of $3^{\text {rd }}$ year & $0.444^{\star *}$ & $0.414^{* *}$ & $0.438^{* *}$ & $0.596^{\star *}$ & $0.504^{\star *}$ & $0.600^{* *}$ & \\
\hline
\end{tabular}

${ }^{\star} p<0.05 ;{ }^{* *} p<0.01$.

correlation between the Quantitative learning score in the spring of the $3^{\text {rd }}$-year and academic achievement in the fall of the $2^{\text {nd }}$-year, as well as the spring and the fall of the $3^{\text {rd }}$-year. Furthermore, the Quantitative learning score in the fall of the $3^{\text {rd }}$-year had a significant negative correlation with improvements in academic achievement. The calculation problem by the point of view and the Quantitative learning scores in the spring of the $2^{\text {nd }}$-year were significantly and positively correlated with the results in the fall of the $1^{\text {st }}$-year, the spring of the $3^{\text {rd }}$-year, and the fall of the $3^{\text {rd }}$-year. Moreover, the Quantitative learning score in the spring of the $3^{\text {rd }}$-year was significantly and positively correlated with the results in the spring and the fall of the $3^{\text {rd }}$-year. Regarding the basic problem, the Quantitative learning scores in the spring of the $2^{\text {nd }}$-year were significantly and positively correlated with the results in the fall of the $1^{\text {st }}$-year, the spring of the $2^{\text {nd }}$-year and the fall of the $2^{\text {nd }}$-year. Also, the Quantitative learning scores in the spring of the $3^{\text {rd }}$-year were significantly and positively correlated with the results in the fall of the $2^{\text {nd }}$-year to the fall of the $3^{\text {rd }}$-year.

Table 6 shows the values of correlation coefficients between the unit results and the Interest and the Quantitative learning scores in all periods. 
Table 5. The correlation coefficients between the Quantitative learning score in each period with comprehensive academic achievement, for each problem group.

\begin{tabular}{|c|c|c|c|c|c|c|c|}
\hline & \multicolumn{2}{|c|}{$1^{\text {st }}$ year } & \multicolumn{2}{|c|}{$2^{\text {nd }}$ year } & \multicolumn{2}{|c|}{$3^{\text {rd }}$ year } & \multirow{2}{*}{ improvement } \\
\hline & spring & fall & spring & fall & spring & fall & \\
\hline \multicolumn{8}{|c|}{ the Quantitative learning score } \\
\hline fall of $1^{\text {st }}$ year & -0.041 & 0.025 & -0.014 & 0.008 & 0.024 & -0.067 & -0.008 \\
\hline spring of $2^{\text {nd }}$ year & 0.053 & $0.162^{* *}$ & $0.129^{*}$ & $0.171^{\star *}$ & $0.167^{* \star}$ & $0.116^{*}$ & -0.056 \\
\hline fall of $2^{\text {nd }}$ year & -0.048 & 0.03 & 0.022 & 0.027 & 0.027 & 0.004 & -0.077 \\
\hline spring of $3^{\text {rd }}$ year & 0.046 & 0.103 & 0.102 & $0.174^{\star *}$ & $0.196^{* *}$ & $0.139^{* *}$ & -0.08 \\
\hline fall of $3^{\text {rd }}$ year & -0.073 & 0.002 & -0.022 & 0.013 & 0.027 & 0.024 & $-0.125^{\star}$ \\
\hline \multicolumn{8}{|c|}{ the Quantitative learning score calculation problem } \\
\hline fall of $1^{\text {st }}$ year & -0.055 & 0.038 & 0.015 & & 0.014 & -0.054 & \\
\hline spring of $2^{\text {nd }}$ year & 0.035 & $0.175^{\star *}$ & 0.083 & & $0.107^{*}$ & $0.123^{*}$ & \\
\hline fall of $2^{\text {nd }}$ year & -0.097 & 0.007 & -0.039 & & 0.025 & 0.002 & \\
\hline spring of $3^{\text {rd }}$ year & 0.002 & 0.105 & 0.067 & & $0.154^{* *}$ & $0.113^{*}$ & \\
\hline fall of $3^{\text {rd }}$ year & -0.055 & 0.02 & -0.026 & & 0.059 & 0.012 & \\
\hline \multicolumn{8}{|c|}{ the Quantitative learning score basic problem } \\
\hline fall of $1^{\text {st }}$ year & -0.089 & -0.042 & -0.065 & 0.029 & 0.03 & -0.03 & \\
\hline spring of $2^{\text {nd }}$ year & -0.013 & $0.132^{\star}$ & $0.116^{*}$ & $0.17^{\star *}$ & 0.099 & 0.087 & \\
\hline fall of $2^{\text {nd }}$ year & -0.042 & 0.006 & -0.027 & 0.08 & 0.053 & 0.069 & \\
\hline spring of $3^{\text {rd }}$ year & 0.02 & 0.099 & 0.052 & $0.176^{* *}$ & $0.145^{\star *}$ & $0.144^{* *}$ & \\
\hline fall of $3^{\text {rd }}$ year & -0.09 & -0.026 & -0.061 & 0.047 & 0 & 0.075 & \\
\hline
\end{tabular}

${ }^{*} p<0.05 ;{ }^{* *} p<0.01$.

Table 6. The values of correlation coefficients between the unit results and Interest and Quantitative learning scores in all periods.

\begin{tabular}{|c|c|c|c|c|c|c|c|}
\hline & $\begin{array}{c}\text { equation } \\
\text { spring of } 2^{\text {nd }} \\
\text { year }\end{array}$ & $\begin{array}{l}\text { proportional and } \\
\text { inverse proportion } \\
\text { spring of } 2^{\text {nd }} \text { year }\end{array}$ & $\begin{array}{c}\text { literal } \\
\text { expression } \\
\text { fall of } 2^{\text {nd }} \text { year }\end{array}$ & $\begin{array}{c}\text { equation } \\
\text { spring of } 3^{\text {rd }} \\
\text { year }\end{array}$ & $\begin{array}{c}\text { linear function } \\
\text { spring of } 3^{\text {rd }} \\
\text { year }\end{array}$ & $\begin{array}{c}\text { number of } \\
\text { cases } \\
\text { fall of } 3^{\text {rd }} \text { year }\end{array}$ & $\begin{array}{c}\text { quadratic } \\
\text { function } \\
\text { fall of } 3^{\text {rd }} \text { year }\end{array}$ \\
\hline \multicolumn{8}{|l|}{ the Interest score } \\
\hline fall of $1^{\text {st }}$ year & $0.437^{* *}$ & $0.370^{* *}$ & $0.452^{* *}$ & $0.437^{* *}$ & $0.440^{* *}$ & $0.290^{* *}$ & $0.294^{* *}$ \\
\hline spring of $2^{\text {nd }}$ year & $0.449^{* *}$ & $0.380^{* *}$ & $0.439^{* *}$ & $0.471^{* *}$ & $0.435^{* *}$ & $0.284^{* *}$ & $0.321^{* *}$ \\
\hline fall of $2^{\text {nd }}$ year & $0.451^{* *}$ & $0.405^{* *}$ & $0.459^{* *}$ & $0.503^{* *}$ & $0.522^{* *}$ & $0.364^{* *}$ & $0.310^{* *}$ \\
\hline spring of $3^{\text {rd }}$ year & $0.435^{\star *}$ & $0.399^{* *}$ & $0.496^{* *}$ & $0.507^{* *}$ & $0.502^{* *}$ & $0.344^{* *}$ & $0.361^{* *}$ \\
\hline fall of $3^{\text {rd }}$ year & $0.434^{* *}$ & $0.382^{* *}$ & $0.497^{* *}$ & $0.557^{* *}$ & $0.497^{\star *}$ & $0.440^{* *}$ & $0.423^{* *}$ \\
\hline \multicolumn{8}{|c|}{ the Quantitative learning score } \\
\hline fall of $1^{\text {st }}$ year & 0.035 & -0.049 & 0.016 & 0.013 & 0.052 & -0.035 & -0.098 \\
\hline spring of $2^{\text {nd }}$ year & $0.139^{\star *}$ & 0.090 & $0.111^{*}$ & $0.163^{* *}$ & $0.203^{\star \star}$ & 0.065 & 0.046 \\
\hline fall of $2^{\text {nd }}$ year & 0.102 & 0.006 & 0.024 & 0.016 & 0.019 & 0.027 & -0.088 \\
\hline spring of $3^{\text {rd }}$ year & $0.130^{*}$ & 0.089 & $0.129^{*}$ & $0.154^{* *}$ & $0.212^{* \star}$ & $0.147^{\star *}$ & 0.036 \\
\hline fall of $3^{\text {rd }}$ year & -0.010 & 0.008 & 0.003 & 0.017 & 0.027 & 0.075 & -0.045 \\
\hline
\end{tabular}

${ }^{*} p<0.05 ;{ }^{* *} p<0.01$. 
It can be seen from Table 6 that there were significant correlations between unit results and the Interest scores in all periods. The Quantitative learning scores in the spring of the $2^{\text {nd }}$ year were significantly and positively correlated with the use of equations in the spring of the $2^{\text {nd }}$-year, the use of literal expressions in the fall of the $2^{\text {nd }}$-year, the use of equations in the spring of the $3^{\text {rd }}$-year, and the use of linear functions in the spring of the $3^{\text {rd }}$-year. Also, the Quantitative learning scores in the spring of the $3^{\text {rd }}$-year were significantly and positively correlated with the use of literal expressions in the fall of the $2^{\text {nd }}$-year, the use of the equations in the spring of the $3^{\text {rd }}$-year, the use of linear functions in the spring of the $3^{\text {rd }}$-year.

\subsection{Relationships between Changes in the Interest Scores, the Quantitative Learning Scores, and Academic Achievement}

The correlation coefficients between changes in the Interest at each time period and comprehensive academic achievement at each time period, improvements in achievement, the results of calculation problem and basic problem by the point of view are shown in Table 7.

It can be seen from Table 7 that changes in the Interest score from the spring of the $3^{\text {rd }}$-year to the fall of the $3^{\text {rd }}$-year were significantly and positively correlated with academic achievement in the fall of the $3^{\text {rd }}$-year. However, no significant correlations were observed between any time period and improvements in

Table 7. The correlation coefficients between changes in the Interest at each time period and comprehensive academic achievement at each time period, for each problem group.

\begin{tabular}{|c|c|c|c|c|c|c|c|}
\hline & \multicolumn{2}{|c|}{$1^{\text {st }}$ year } & \multicolumn{2}{|c|}{$2^{\text {nd }}$ year } & \multicolumn{2}{|c|}{$3^{\text {rd }}$ year } & \multirow{2}{*}{ improvemen } \\
\hline & spring & fall & spring & fall & spring & fall & \\
\hline change in the Interest & \multicolumn{6}{|c|}{ comprehensive academic achievement } & \\
\hline fall of $1^{\text {st }}$ year to spring of $2^{\text {nd }}$ year & 0.001 & 0.004 & 0.027 & 0.032 & 0.064 & 0.062 & -0.059 \\
\hline spring of $2^{\text {nd }}$ year to fall of $2^{\text {nd }}$ year & 0.017 & -0.028 & 0.011 & 0.069 & 0.069 & 0.052 & -0.024 \\
\hline fall of $2^{\text {nd }}$ year to spring of $3^{\text {rd }}$ year & -0.03 & 0.003 & 0.012 & 0.013 & 0.011 & 0.015 & -0.058 \\
\hline spring of $3^{\text {rd }}$ year to fall of $3^{\text {rd }}$ year & 0.101 & 0.091 & 0.05 & 0.041 & 0.084 & $0.139^{* *}$ & 0.007 \\
\hline change in the Interest & \multicolumn{4}{|c|}{ calculation problem } & & & \\
\hline fall of $1^{\text {st }}$ year to spring of $2^{\text {nd }}$ year & 0.046 & 0.025 & 0.006 & & 0.034 & 0.062 & \\
\hline spring of $2^{\text {nd }}$ year to fall of $2^{\text {nd }}$ year & -0.018 & -0.038 & 0.005 & & 0.093 & 0.056 & \\
\hline fall of $2^{\text {nd }}$ year to spring of $3^{\text {rd }}$ year & -0.015 & 0.002 & 0.003 & & -0.017 & 0 & \\
\hline spring of $3^{\text {rd }}$ year to fall of $3^{\text {rd }}$ year & 0.054 & 0.025 & 0.061 & & $0.139^{\star *}$ & 0.102 & \\
\hline change in the Interest & \multicolumn{4}{|c|}{ basic problem } & & & \\
\hline fall of $1^{\text {st }}$ year to spring of $2^{\text {nd }}$ year & 0.048 & 0.09 & 0.084 & 0.018 & 0.044 & 0.029 & \\
\hline spring of $2^{\text {nd }}$ year to fall of $2^{\text {nd }}$ year & 0.025 & -0.088 & -0.045 & $0.118^{\star}$ & 0.036 & 0.069 & \\
\hline fall of $2^{\text {nd }}$ year to spring of $3^{\text {rd }}$ year & -0.018 & 0.058 & 0.074 & -0.002 & 0.045 & 0.022 & \\
\hline spring of $3^{\text {rd }}$ year to fall of $3^{\text {rd }}$ year & 0.088 & 0.021 & 0.008 & 0.093 & 0.053 & $0.172^{\star *}$ & \\
\hline
\end{tabular}

${ }^{*} p<0.05 ;{ }^{* *} p<0.01$. 
academic achievement. Also, changes in the Interest score from the spring of the $3^{\text {rd }}$-year to the fall of the $3^{\text {rd }}$-year were significantly and positively correlated with the results of calculation problem by the point of view in the spring of the $3^{\text {rd }}$-year. Furthermore, change in the Interest score from the spring of the $2^{\text {nd }}$-year to the fall of the $2^{\text {nd }}$-year was significantly and positively correlated with the results of the basic problem in the fall of the $2^{\text {nd }}$-year. Additionally, changes in the Interest score from the spring of the $3^{\text {rd }}$-year to the fall of the $3^{\text {rd }}$-year were significantly and positively correlated with the results of the basic problem in the fall of the $3^{\text {rd }}$-year.

Table 8 shows the correlations between changes in the Quantitative learning score at each time period and comprehensive academic achievement at each time, for each problem group.

It can be seen from Table 8 that changes in the Quantitative learning scores from the fall of the $1^{\text {st }}$-year to the spring of the $2^{\text {nd }}$-year were significantly and positively correlated with academic achievement from the fall of the $1^{\text {st }}$-year to the fall of the $3^{\text {rd }}$-year. However, changes from the spring of the $2^{\text {nd }}$-year to the fall of the $2^{\text {nd }}$-year were significantly and negatively correlated with all the academic achievement scores from the fall of the $1^{\text {st }}$-year to the fall of the $3^{\text {rd }}$-year. Also changes from the fall of the $2^{\text {nd }}$-year to the spring of the $3^{\text {rd }}$-year were significantly and positively correlated with academic achievement from the fall of the $2^{\text {nd }}$-year to the spring of the $3^{\text {rd }}$-year. Finally, Changes from the spring of the

Table 8. The correlations between changes in the Quantitative learning score at each time period and comprehensive academic achievement at each time, for each problem group.

\begin{tabular}{|c|c|c|c|c|c|c|c|}
\hline & \multicolumn{2}{|c|}{$1^{\text {st }}$ year } & \multicolumn{2}{|c|}{$2^{\text {nd }}$ year } & \multicolumn{2}{|c|}{$3^{\text {rd }}$ year } & \multirow{2}{*}{ improvement } \\
\hline & spring & fall & spring & fall & spring & fall & \\
\hline change in the quantitative learning & \multicolumn{7}{|c|}{ comprehensive academic achievement } \\
\hline fall of $1^{\text {st }}$ year to spring of $2^{\text {nd }}$ year & 0.093 & $0.14^{\star *}$ & $0.146^{* *}$ & $0.166^{* *}$ & $0.146^{* *}$ & $0.186^{* *}$ & -0.048 \\
\hline spring of $2^{\text {nd }}$ year to fall of $2^{\text {nd }}$ year & -0.096 & $-0.133^{*}$ & $-0.107^{\star}$ & $-0.144^{\star *}$ & $-0.14^{* \star}$ & $-0.111^{\star}$ & -0.016 \\
\hline fall of $2^{\text {nd }}$ year to spring of $3^{\text {rd }}$ year & 0.093 & 0.09 & 0.095 & $0.172^{* *}$ & $0.196^{* *}$ & $0.153^{* *}$ & -0.022 \\
\hline spring of $3^{\text {rd }}$ year to fall of $3^{\text {rd }}$ year & $-0.109^{*}$ & -0.092 & $-0.112^{*}$ & $-0.146^{\star *}$ & $-0.154^{* *}$ & -0.104 & -0.043 \\
\hline change in the quantitative learning & \multicolumn{7}{|c|}{ calculation problem } \\
\hline fall of $1^{\text {st }}$ year to spring of $2^{\text {nd }}$ year & 0.091 & $0.14^{* *}$ & 0.069 & & 0.095 & $0.18^{* *}$ & \\
\hline spring of $2^{\text {nd }}$ year to fall of $2^{\text {nd }}$ year & $-0.123^{*}$ & $-0.167^{\star *}$ & $-0.118^{*}$ & & -0.083 & $-0.119^{*}$ & \\
\hline fall of $2^{\text {nd }}$ year to spring of $3^{\text {rd }}$ year & 0.086 & $0.112^{*}$ & $0.109^{*}$ & & $0.151^{\star *}$ & $0.124^{*}$ & \\
\hline spring of $3^{\text {rd }}$ year to fall of $3^{\text {rd }}$ year & -0.051 & -0.077 & -0.085 & & -0.087 & -0.092 & \\
\hline change in the quantitative learning & \multicolumn{7}{|c|}{ basic problem } \\
\hline fall of $1^{\text {st }}$ year to spring of $2^{\text {nd }}$ year & 0.077 & $0.177^{\star *}$ & $0.185^{\star *}$ & $0.143^{* \star}$ & 0.071 & $0.119^{*}$ & \\
\hline spring of $2^{\text {nd }}$ year to fall of $2^{\text {nd }}$ year & -0.025 & $-0.125^{\star}$ & $-0.14^{\star *}$ & -0.094 & -0.049 & -0.023 & \\
\hline fall of $2^{\text {nd }}$ year to spring of $3^{\text {rd }}$ year & 0.059 & $0.107^{\star}$ & 0.082 & $0.127^{\star}$ & $0.116^{*}$ & 0.101 & \\
\hline spring of $3^{\text {rd }}$ year to fall of $3^{\text {rd }}$ year & -0.1 & $-0.114^{*}$ & -0.103 & $-0.117^{\star}$ & $-0.132^{*}$ & -0.062 & \\
\hline
\end{tabular}

${ }^{\star} p<0.05 ;{ }^{* *} p<0.01$. 
$3^{\text {rd }}$-year to the fall of the $3^{\text {rd }}$-year were significantly and negatively correlated with the results in the spring of the $1^{\text {st }}$-year and results from the spring of the $2^{\text {nd }}$ year to the spring of the $3^{\text {rd }}$-year. There were no significant correlations at any time with improvements in academic achievement. The changes in the Quantitative learning score from the fall of the $1^{\text {st }}$ year to the spring of $2^{\text {nd }}$ year were significantly and positively correlated with results of calculation problem by the point of view in the fall of the $1^{\text {st }}$-year and in the fall of the $3^{\text {rd }}$-year. The changes in the Quantitative learning score from the spring of the $2^{\text {nd }}$-year to the fall of the $2^{\text {nd }}$-year was significantly and negatively correlated with the result in the spring of the $1^{\text {st }}$-year and in the fall of the $1^{\text {st }}$-year, in the spring of the $2^{\text {nd }}$-year, as well as in the fall of the $3^{\text {rd }}$ year. Changes in the Quantitative learning score from the fall of the $2^{\text {nd }}$-year to the spring of the $3^{\text {rd }}$-year were significantly and positively correlated with the result in the fall of the $1^{\text {st }}$-year and in the spring of the $2^{\text {nd }}$-year, as well as in the spring and the fall of the $3^{\text {rd }}$-year.

The change in the Interest score from the fall of the $1^{\text {st }}$-year to the spring of the $2^{\text {nd }}$-year was significantly and positively correlated with the results of the basic problem in the fall of the $1^{\text {st }}$-year, the spring of the $2^{\text {nd }}$-year, the fall of the $2^{\text {nd }}$-year, and the fall of the $3^{\text {rd }}$-year. The change in the Interest score from the fall of the $2^{\text {nd }}$ year to the spring of the $3^{\text {rd }}$-year was significantly and positively correlated with the results of the basic problem in the fall of the $1^{\text {st }}$-year, the fall of the $2^{\text {nd }}$-year, and the spring of the $3^{\text {rd }}$-year. The change in the Interest score from the spring of the $2^{\text {nd }}$-year to the fall of the $2^{\text {nd }}$-year was significantly and negatively correlated with the results of the basic problem in the fall of the $1^{\text {st }}$-year, and the spring of the $2^{\text {nd }}$-year. The changes in the Interest score from the spring of the $3^{\text {rd }}$-year to the fall of the $3^{\text {rd }}$-year were significantly and negatively correlated with the results of the basic problem in the fall of the $1^{\text {st }}$-year, the fall of the $2^{\text {nd }}$-year, and the spring of the $3^{\text {rd }}$-year.

\section{Discussion}

\subsection{Items on Consciousness about Mathematics}

Items were developed to facilitate the Quantitative evaluation of the consciousness about mathematical in the education of junior high school students. As a result, two factors were extracted as subscales: the Interest score factor indicating the interest in mathematics and the Quantitative learning score factor indicating mathematics learning time. Then, an analysis of mathematics education in junior high schools was conducted on academic achievement, interest in mathematics and mathematics learning time.

\subsection{Grade Differences in the Items on Consciousness about Mathematics}

The results indicated no significant difference in the Interest scores after the fall of the $1^{\text {st }}$-year, suggesting that interest in mathematics is determined before entering to six months after entering junior high school. However, this study did 
not examine consciousness about mathematics before or immediately after entering junior high school. Therefore, consciousness about mathematics from entering junior high school to the fall of the first year was not clarified. Moreover, this study did not examine the influence of periodic tests results after entering junior high school consciousness about mathematics. As a result, it was not possible to identify factors influencing consciousness about mathematics until the fall of the $1^{\text {st }}$-year. It is suggested that future studies conduct additional investigations to identify consciousness about mathematics from entrance to junior high school to the fall, as well as the relationship between the consciousness of mathematics after entering junior high school with detailed academic achievement.

The Quantitative learning scores in the fall of the $2^{\text {nd }}$-year tended to be significantly lower than those in all other periods, and they had no significant correlation with academic achievement in any other period. These results indicate that Quantitative learning tends to decline regardless of the grade in the fall of the $2^{\text {nd }}$-year, suggesting that mathematics learning time declines in the fall of the $2^{\text {nd }}$-year. However, a significant negative correlation was observed between changes in the Quantitative. These findings indicate that the Quantitative learning tends to decline in students with high academic achievement after the spring of the $2^{\text {nd }}$-year. Therefore, it is suggested that educational interventions for preventing the declining of Quantitative learning are necessary for students with high academic achievement after the spring of the $2^{\text {nd }}$-year. Such interventions conducted in the fall of the $2^{\text {nd }}$-year should aim to develop a deeper understanding and include more difficult problems. On the other hand, students with low academic achievement tended to increase Quantitative learning. We also found that the increase in Quantitative learning does not correlate with academic achievement. Therefore, it is considered that educational interventions prioritizing mathematical understanding, rather than the amount of learning, is necessary for the fall of the $2^{\text {nd }}$-year for students with low academic achievement.

\subsection{Correlation with Academic Achievement}

The analysis using the Consciousness Scale for Mathematics indicated that the Interest score was strongly correlated, and the Quantitative learning score was weakly correlated with academic achievement. According to Singh (2002) understanding the role of factors as motivation, interest, attitudes, and academic engagement on achievement in mathematics and science has attracted serious attention in recent years. Moreover these are amenable to change by educational opportunities. In order to realize this, it is important to improve the education of teachers, as well as approaches to schools.

Correlational analysis of consciousness and academic achievement indicated a significant positive correlation between improvement of academic achievement and the Interest scores in the fall of the $1^{\text {st }}$-year and the spring and the fall of the $2^{\text {nd }}$-year. This indicates that the Interest scores from the fall of the $1^{\text {st }}$-year to the 
fall of the $2^{\text {nd }}$-year are particularly important for improving academic achievement in mathematics. Moreover, the Interest scores until the fall of the $2^{\text {nd }}$-year had a significant influence on subsequent efforts in mathematics. Based on these findings, it is suggested that educational interventions for the development and improvement of teaching materials are particularly important for maintaining and improving the interest in mathematics during the $1^{\text {st }}$ and $2^{\text {nd }}$ years of mathematics education in junior high schools.

The correlation analysis of consciousness items related to mathematics and academic achievement indicated a significant positive correlation between the Interest score for all periods and academic achievement. Moreover, there was a positive correlation between the Quantitative learning scores and academic achievement in the spring of the $2^{\text {nd }}$ and $3^{\text {rd }}$ years, whereas this correlation was weak in the fall. Furthermore, there was a significant negative correlation between the Quantitative learning score and academic achievement in the $1^{\text {st }}$-year, the $2^{\text {nd }}$-year, and the $3^{\text {rd }}$-year.

\subsection{Differences in the Quantitative Learning Scores between Spring and Fall}

Differences in the Quantitative learning scores were observed between spring and fall, which were related to differences in learning situations. The spring survey was conducted immediately after the start of the new semester, before beginning classes in earnest. So, many students might have assumed that the question on "Study time for mathematics" referred to the spring vacation. The fall survey was conducted immediately after the results of the previous term were out, and was conducted after the deadline of the tasks that are given.

As a result, many students might have responded to the question on "Study time for mathematics" by assuming the tasks that are given. The number of tasks during the spring holidays tends to be less than at the end of the previous term. The self-directed learning tendency might be stronger in the spring, and the tendency to conduct a mixed amount of learning could be strong in the fall. This could explain why students with high academic achievement had high Quantitative learning scores in the spring and low Quantitative learning scores in the fall, whereas students with low academic achievement had low Quantitative learning scores in the spring and high Quantitative learning scores in the fall. In the spring, self-directed Quantitative learning by highly interested students might increase, whereas that by less interested students might decrease. On the other hand, in the fall, a fixed amount of learning is set as the task and students that could understand better might have required less time to learn compared to students that understood less, who required more time to learn.

These findings on learning of mathematics indicate that students with high academic achievement tend to have a high interest in mathematics and do more self-directed Quantitative learning. However, if the quantity of the task is decided, students end up learning by doing only the decided quantity. Therefore, 
in addition to providing tasks, students with high academic achievement need to be encouraged to conduct self-directed learning to improve themselves. Students with low academic achievement tend to be less interested in mathematics and conduct less Quantitative and self-directed learning. Furthermore, Quantitative learning takes longer if it cannot be understood. This is a negative factor to consciousness about mathematics, and it will likely cause a decrease in interest, thus, doing a few tasks beyond understanding. These results suggest that it is necessary to support the advancement of such students while carefully and steadily considering the tasks according to their understanding.

\section{Conclusion}

This study developed items assessing the Interest and the Quantitative learning, which are related to mathematical consciousness. Three question items assessed the Interest factor and two question items assessed the Quantitative learning factor. These factors are considered highly reliable because a longitudinal survey was conducted for three years with three generations of students. Therefore, the items of the Consciousness about Mathematics Scale could accurately identify the consciousness of junior high school students about mathematics. Moreover, these items were expected to be effective for developing interventions to improve students' education.

It is generally believed that motivation and interests are strongly related to academic achievement. Therefore, guiding students by using items on consciousness about mathematics obtained from this research would facilitate identifying students' situation from the perspectives of "Interest" and "Quantitative learning”, which could be effective indices for selecting strategies of educational intervention.

However, this research could identify only average values by grouping each Interest score. Moreover, the Quantitative learning score was not analyzed. Therefore, the applicability of these findings to understanding students could be limited. It is suggested that future studies should deeply analyze the students' situation. Moreover, there are certain unresolved issues in this research. Nevertheless, this study could identify question items for evaluating students' consciousness about mathematics from the perspectives of the Interest and the Quantitative learning. These items can be used for developing educational interventions for mathematics classes in junior high schools. Moreover, the results suggested that educational interventions for preventing the decline of Quantitative learning are required by students with high academic achievement in the fall of the $2^{\text {nd }}$-year. Educational Interventions to prevent the decline of Quantitative learning should include programs for developing a deeper understanding in the fall of the $2^{\text {nd }}$-year. The study also indicated that students with low academic achievement in the fall of the $2^{\text {nd }}$-year require educational interventions prioritizing the understanding of mathematics, rather than the quantity of learning.

It is expected that these new and important findings on correlations between 
the consciousness of junior high school students and academic achievement in mathematics would contribute to mathematics education in Japan and other countries in the future.

\section{Conflicts of Interest}

The authors declare no conflicts of interest regarding the publication of this paper.

\section{References}

Anderman, E. M., \& Midgley, C. (1997). Changes in Achievement Goal Orientations, Perceived Academic Competence, and Grades across the Transition to Middle-Level Schools. Contemporary Educational Psychology, 22, 269-298. https://doi.org/10.1006/ceps.1996.0926

Carnegie Council on Adolescent Development (1995). Great Transitions: Preparing Adolescents for the New Century. New York: Carnegi.

Eccles, J. S., \& Jacobs, J. E. (1986). Social Forces Shape Math Attitudes and Performance. Signs: Journal of Women in Culture and Society, 11, 367-380. https://doi.org/10.1086/494229

Eccles, J. S., \& Midgley, C. (1989). Stage/Environment Fit: Developmentally Appropriate Classrooms for Early Adolescence. In R. E. Ames, \& Ames, C. (Eds.), Research on Motivation in Education (Vol. 3, pp. 139-186). New York: Academic Press.

Eccles, J. S., Midgley, C., Buchanan, C. M., Flanagan, C., Mac Iver, D., Reuman, D., \& Wigfield, A. (1993). Development during Adolescence: The Impact of Stage/Environment Fit. The American Psychologist, 48, 90-101. https://doi.org/10.1037/0003-066X.48.2.90

Kawachi, Y., Chuman, G. \& Iwata, K. (2000). The Structure Which Examines Why Mathematics Is Hated: The Consciousness of the Student of Junior High School and University in the Free Description. Gifu: Curriculum Research \& Development Center, Faculty of Education, Gifu University, 1-12.

Ministry of Education, Culture, Sports, Science and Technology (2015). Survey Results of International Mathematics and Science Education Trend Survey (TIMSS).

http://www.mext.go.jp/component/a_menu/education/micro_detail/_icsFiles/afieldfil e/2016/12/27/1379931_1_1.pdf

Ministry of Education, Culture, Sports, Science and Technology (MEXT) (2017). Survey Report on National Academic Ability and Learning Situation. http://www.nier.go.jp/17chousakekkahoukoku/report/data/17qn.pdf

Oie, M., \& Fujie, Y. (2007). Motivation on Science and Mathematics across Elementary School to Junior High School: Making Measurement of Motivation on Mathematics. Bulletin of the Research Center for Child and Adolescent Development and Education, 4, 75-81.

Okado, K., Yoshida, H., \& Kida, N. (2017). Correlations between Changes in Study Habits and Academic Results in Junior High School Students-A Longitudinal Survey at a Private Junior High School. Psychology, 8, 2102-2113. https://doi.org/10.4236/psych.2017.813133

Reynolds, A. J. (1991). The Middle Schooling Process: Influences on Science and Mathematics Achievement from the Longitudinal Study of American Youth. Adolescence, 26, 132-157.

Reynolds, A. J., \& Walberg, H. J. (1992). A Structural Model of Science Achievement and 
Attitude: An Extension to High school. Journal of Educational Psychology, 84, 371-382. https://doi.org/10.1037/0022-0663.84.3.371

Simmons, R. G., \& Blyth, D. A. (1987). Moving into Adolescence: The Impact of Pubertal Change and School Context. Hawthorne, NJ: Aldine.

Singh, K., Granville, M., \& Dika, S. (2002). Mathematics and Science Achievement: Effects of Motivation, Interest, and Academic Engagement. The Journal of Educational Research, 95, 323-332. https://doi.org/10.1080/00220670209596607

Skaalvik, E. M., \& Rankin, R. J. (1995). A Test of the Internal/External Frame of Reference Model at Different Levels of Math and Verbal Self-Perception. American Educational Research Journal, 32, 161-184. https://doi.org/10.3102/00028312032001161

Uchida, A. \& Mori, K. (2012). Do Junior High School Students Really Hate Mathematics and Science?: Implications for Educational Practices from a Research Utilizing an Implicit Assessment Measure. Journal for the Science of Schooling, 13, 221-227. 